\title{
Language as a Means of Power: A Comparative Study of Harold Pinter's No Man's Land and Alfred Farag's Ali Janah al-Tabrizi and His Servant Quffa
}

\author{
Usama Raslan*
}

This paper is an attempt to examine how the British Nobel- laureate dramatist, Harold Pinter (1930-2008), and the Egyptian versatile writer, Alfred Farag (1929-2005), depict the power struggle between two dramatic characters obsessed by a conflict of wills. The plays under study are Pinter's No Man's Land (1975), and Farag's Gali: Ganaћ al-Tabri:zi: wa tabiSuhu Quffah ${ }^{\mathbf{1}}$ (1969 [translated into English by Rasheed El-Enany and Charles Doria as Ali Janah alTabrizi and His Servant Quffa]). Both plays are analyzed in the light of Foucault's theory of power and Wittgenstein's theory of language games, to prove that language is a medium through which efforts for dominance are exerted among individuals. This motif explains how one character employs language as a means of gaining power to direct and determine the behavior of the other. To achieve such an objective, the paper concentrates on how both playwrights draw extensively on a theatrical language that dramatizes the power struggle between characters as well as the linguistic tactics employed by them to sustain their desire for power.

In order to fully comprehend how power is exercised among individuals, one should consider that power, as this paper argues, is a tying relationship among individuals, a relationship in terms of which one character tries to direct and govern the behavior of another by adopting multiple forms of linguistic tactics/language games. When comparing Pinter's No Man's Land to Farag's Ali Janah al-Tabrizi and His Servant Quffa, one can discover that the thematic schema of both plays shows how the struggle for power is manipulated and actualized by the same linguistic strategies, or rather language games. In this regard, Pinter's theatre is described as "a theatre of language" (Esslin 40), where words become weapons that give rise to "suspense, dramatic tension, laughter and tragedy" (40). This denotes that language is the key point in terms of which one can probe deeply into a Pinteresque drama to better understand the relationship between characters and power struggle. By so doing, one can infer that through language, a Pinteresque character defines "its mode of being, which

\footnotetext{
* October 6 University.
} 
is reflected in his/her response towards a concrete state of affairs, a specific object, individual or relationship" (Rosca 11) of power.

Like Pinter's theatre, Farag's can be described as a theatre of language. This epithet can be traced back to the fact that Farag is one of the most accomplished Arab playwrights who creates a special dramatic language. His theatrical language does not include "contrived imagery and convoluted linguistic constructions; it is stimulating to read and easily comprehended in performance" (Amin 46). Holding that a Farag play can be perceived in performance, one can conclude that Farag creates a new dramatic language that helps him convey his dramatic vision, a vision that aims at revealing the power struggle within which the dramatic characters are entangled. To dramatize such a struggle, Farag draws a comparison between literary and dramatic language. Such a Farag comparison leads one to estimate that what distinguishes the dramatic language from the literary one is that the former is an aesthetic instrument that results from dialogues between characters: "the literary language, whether colloquial or formal, has its own expressive and aesthetic objectives. On the contrary, the theatrical language is completely different; it is an aesthetic artistic instrument that springs from the exchanged dialogue among characters"2 (Farag Dali:l almutafarrig al-ðakij 163 [trans. mine]). Farag lays heavy emphasis on the aesthetic function fulfilled by dramatic dialogue in negotiating relationships of power.

In highlighting such relationships, the two plays under study can be analyzed in the light of Foucault's theory of power. This theory implies that "there is no power that is exercised without a series of aims and objectives" (Foucault Truth and Power 95). Such an approach, when applied to the analysis of Pinter's No Man's Land and Farag's Ali Janah al-Tabrizi and His Servant Quffa, shows that both playwrights are practitioners in a theatrical school established by Foucault and Wittgenstein. Although Pinter and Farag do not voice the aesthetic impact of Foucault and Wittgenstein's philosophies on their dramatic oeuvre, their dramatic pieces are identical with the power mechanisms outlined by such two philosophers. Both plays provide a plot that revolves around two characters locked in a battle for control that stems from their desire for power. This thematic structure elucidates that power relations, to use Jean-Francois Lyotard's terms, are "composed of language moves" (10), or rather language games. Such games (moves), invented by the dramatic characters, reflect how language can be used as a means to maintaining and imposing power.

In comparing the two plays, significant plot parallels regarding the issue of power can be discovered. No Man's Land, a two-act play, tells the story of Hirst, a successful poet, who invites Spooner, a failed poet, home for a drink. The play revolves around power struggle - Sponner's attempt to find a secure haven at 
Hirst's home. His attempt, unfortunately, is doomed to failure, mainly because Hirst stands out against any attempt to disturb his fabricated existence. This thematic structure indicates that the struggle for power is an important aspect of Pinter's play, which brings to light the notion that "all human contact is a battle between who and whom" (Billington 2).

In similar ways, Farag composes a two-act play inspired by tales from The Arabian Nights in order to illustrate the power issue. Such tales are fused together to produce a plot that depicts the story of Ali Janah al-Tabrizi, a young man from "a wealthy family who has squandered his inheritance and has now become impoverished" (Leeuwen 215). When Quffa, a poor cobbler dressed in rags, drops into al-Tabrizi's house asking for hospitality, al-Tabrizi welcomes him, ordering the servant to provide an imaginary banquet for his guest. This imaginary banquet endows al-Tabrizi with a chance to exercise power over Quffa by convincing him to be his follower and servant in a journey to a distant land, the mountain Qaf, where al-Tabrizi uses the power of language to change reality. In so doing, al-Tabrizi tricks the citizens and the King of such a land into holding that he is a rich merchant waiting for the arrival of a great caravan. This lie stirs the greed of the king and other merchants as they lend him large amounts of money, "hoping for his generous reward when his caravan arrives" (Amin 42). However, al-Tabrizi depletes the king and the merchants' safe, running away accompanied by Quffa and the princess whom he has married. This thematic structure implies that Ali Janah al-Tabrizi and His Servant Quffa is almost as clear as No Man's Land: both plays dramatize the idea of power struggle, particularly how Pinter's Spooner and Farag's al-Tabrizi use language as a strategy to overpower the other, Hirst and Quffa.

A close reading of the selected plays elucidates that though Pinter and Farag belong to different cultural milieus, both are identical in dramatizing the same leitmotif of power struggle. Such a leitmotif helps them both show how their characters use language as a device to attain power by imposing their space position as a supreme law. In so doing, the present study explores the relationship between power and language by proving that both dramatists compose a dramatic discourse whose speech patterns are nothing more than an instrument to negotiate such a relationship. To realize such an aim, it is useful to proceed first with an overview of Foucault's theory of power and Wittgenstein's language games in relation to Pinter and Farag's dramaturgy.

Michel Foucault (1926-1984), the French theorist of history and systems of thought, is considered the forerunner of shaping an aesthetic understanding of power. He is regarded as the founder of the theory of power. His philosophy introduces two forms of power: "Power-with a capital P" and "power relations" 
with a small p (Foucault Aesthetics, Method, and Epistemology 451). In Foucault's estimation, the former refers to the political and economic Power practiced by the State, while the latter stands for power relations incarnated by all members of a society who are overwhelmed by a desire for power. In trying to exercise such a power within the society, the individuals interact with each other. This interaction denotes that power is not a concrete concept. Rather, it is a relationship between two individuals in terms of which one has an urgent desire to "direct" and "determine" the behavior of the other. For all that, thinkers misunderstand the idea of power by drawing an analogy between power and government, mainly because power is a relationship used everywhere in any society to refer to multiple forms of controlling the other. Power can be practiced by anyone who longs for governing a society, a group, a community, or another person. To accomplish such a target, the individuals of a society give voice to their will to direct and dominate the behavior of the other in terms of "a strategy" by resorting to a number of linguistic "tactics." Foucault remarks:

Power is relationships; power is not a thing, it is a relationship between two individuals, a relationship which is such that one can direct the behavior of another. ... One can govern a society, one can govern a group, a community, a family; one can govern a person. When I say "govern someone," it is simply in the sense that one can determine one's behavior in terms of a strategy by resorting to a number of tactics. (Foucault Live 410)

To determine the behavior of the other, the individual should resort to a number of tactics. Such tactics can only be discovered in Wittgenstein's theory of language games. Ludwig Wittgenstein (1889-1951), an Austrian British philosopher, is considered the greatest philosopher in the $20^{\text {th }}$ century. Although he did not write a single work on aesthetics, his theory of language games attempts to bridge the gap between power-relations and communicationrelations. In his book, Philosophical Investigations (1958), Wittgenstein introduces this theory in terms of a very primitive language. He asks the readers to imagine a primitive form of language in which language is used as a means of communication between two parties: a builder A/the speaker and assistant $\mathrm{B} /$ the addressee. $\mathrm{A}$ is building with certain materials like blocks, pillars, slabs, and beams. The function of B is to pass such materials in the order in which $A$ needs them. In a sense, they employ language that sustains their communication, a language in which $\mathrm{A}$ gives orders and $\mathrm{B}$ has no option except obeying such orders. The interaction between A and B simplifies what Wittgenstein means by language game that goes like that: when the builder/A utters the word 'slab', his 
assistant/B brings him the object that is needed. The builder uses the power of language to force the assistant to carry out a certain task on hearing words as "blocks," "pillars," "slabs," and "beams." His language illustrates the role played by language game in subduing the other. This is the natural law of language game: one gives orders, and the other has to obey him/her:

The language is meant to serve for communication between a builder $\mathrm{A}$ and an assistant B. A is building with building-stones: there are blocks, pillars, slabs and beams. B has to pass the stones, and that in the order in which A needs them. For this purpose they use a language consisting of the words "block", "pillar", "slab", "beam". A calls them out;-B brings the stone which he has learnt to bring at such-and-such a call. (3)

The reaction of the assistant to the words of the builder indicates that a "kind of rapport is established between the builder and the assistant" (Ara 48) with such words as "block", "pillar", "slab", "beam". Such rapport is the reason behind the appearance of the language game which contends that "block", "pillar", "slab" or "beam" is not "a description, but an order or an appeal" (Ara 48). In this regard, Wittgenstein's theory of language games highlights how a human subject can use language as a tactic to direct and determine the behavior of the other.

Foucault's concept of power and Wittgenstein's theory of language games are best depicted in Pinter's No Man's Land and Farag's Ali Janah al-Tabrizi and His Servant Quffa. These two pieces have the same thematic schema: how the characters approach language as a tactic for governing and controlling each other. This critical practice places both playwrights among the forerunners of the philosophy of power as well as a theatrical language that brings to light the relationship between language and power struggle. In his essay, "Introduction: Writing for the Theatre" (1996), Pinter analyzes the aesthetic interaction between language and reality. His analysis elucidates that what theatre represents is not a reality, but a version of it. He goes on stating that there is no static interpretation of "a common experience," partly because "language is a highly ambiguous business." To avoid such an ambiguity, the dramatist should provide the characters with an aesthetic space so as to negotiate with each other and express power struggle, using language as a tactic to "reveal the thing known and unspoken." This critical practice indicates that the dramatist should depend on an aesthetic stage dialogue that gives the characters a chance to describe their aspirations, motives and history as well as their desire for power in terms of language games. The interaction between the dramatist and his characters creates "a territory," an aesthetic construct that enables the audience/reader to 
comprehend how the conversant in a dramatic dialogue manipulates language to determine the behavior of each other. In this respect, the audience/reader can find out that "under what is said, another thing is being said" (xii). This dramatic practice is the outcome of a respectful relationship between the author and characters, a relationship that helps the characters unfold the power struggle that dominates their speech patterns. To set up such a relationship, Pinter insists that the dramatist should equip the characters with a "legitimate elbowroom" by which the unspoken/power relation can be interpreted. He argues:

Language ... is a highly ambiguous business. So often, below the word spoken, is the thing unknown and unspoken. ... The relationship between author and characters should be a highly respectful one, both ways. And if it's possible to talk of gaining a kind of freedom from writing, it doesn't come by leading one's characters into fixed and calculated postures, but by allowing them to carry their own can, by giving them a legitimate elbowroom. (xii)

In his book, Dali:l al-mutafarrig al-ðakij Pala al-masraћ (1989), Farag examines the distinguishing features of dramatic dialogue. He argues that dramatic dialogue is the essence of theatre. It is the best medium through which the struggle of power can be best illustrated. Dialogue gives a clear indication of the existence of opposing interests, ideologies and power-relations between characters, mainly because it stands for a struggle between two parties: a speaker and an addressee. Each party, overwhelmed by a desire for power, attempts to govern and direct the behavior of the other. Farag observes:

Dramatic dialogue represents a form of struggle that results from a clash between two human forces, two natural systems, or two contradicting wills. Such a struggle should end with the victory of one power over the other. ... Thus, the dramatic dialogue between characters is a truthful expression of the conflicting desires that sublimate the struggle as well as the dramatic action. Such desires enable the dramatic dialogue to end up with the final and fatal collision between the speaker and addressee by asserting the total victory of one party over the other. (159f )

That is to say, the interaction among characters reflects not only the power struggle that deepens the dialogue, but also how each character draws on the power of language to impose his/her will on the other in terms of linguistic tactics. Such tactics indicate that "theatre is in need of a stage language; a wellfocused expressive language that expresses in a direct clear way the struggle 
between characters to help the audience/reader conclude that below the spoken word, is the thing unknown and unspoken" (163f).

Pinter and Farag's concept of the aesthetic interaction between the dramatic dialogue and stage language motivates one to infer that both writers hold the same dramatic vision. The very objective of such a vision is to dramatize how language can be used as a means of subduing the other. However different their language, culture and nations might be, both writers, to use Rosca's terms, contend that "power is not a pre-given fact, but an attribute that has to be acquired and reacquired through a variety of strategies" (7). Both dramatists are preoccupied with the issue of power, or rather the relationship between powerrelations and communication-relations. To encapsulate such relationships, both create a multitude of linguistic tactics that help the dramatic characters attain power by "imposing their singular space position as the supreme law" (Rosca 10) on the other. This is the leitmotif that dominates the two plays under study as well as the oeuvre of both playwrights. To theatricalize such a leitmotif, both Pinter and Farag demonstrate how the analysis of power relations characterizes "the manner in which men are 'governed' by one another" (Foucault 1997 463). In a word, both writers are consistently recognized for their innovation in dramatic language that highlights the power struggle between characters. Both of them develop a theatrical language that fits their dramatic project which, to use Quigley's words, employs theatre as “an instrument to negotiate relationship of power" (54). In so doing, both writers shed light on the aesthetic value played by the stage language in illuminating power relationships. This assessment is best reflected in No Man's Land and Ali Janah al-Tabrizi and His Servant Quffa.

To negotiate power relationships, Pinter's No Man's Land rotates around the idea of power struggle. In order to dramatize such a struggle, the play represents "a battle between two men, one trying futilely to escape the isolation of the artist's perspective, the other trying, equally futilely, to gain it" (Latrell 160). This battle results from a power struggle between Hirst who tries vainly to escape the isolation; and Spooner who seeks to gain it, as well as the power strategies adopted by both characters to maintain and direct the behavior of each other. To direct the behavior of Hirst, Spooner exercises four forms of linguistic activities, or what Wittgenstein calls Language games, which express his desire for power. His games include flattery, giving orders, bettering himself and helping Hirst. These are the four tactics in terms of which Spooner attains power that helps him impose himself on the fabricated existence of Hirst. What is axiomatic is that whenever a tactic fails, he never hesitates to try another one, waiting for the reaction of Hirst. This can be related back to the fact that Spooner is an outsider who aims to win the favor of his host. His only weapon in this struggle is "the power of speech, and he successfully dominates the conversation 
with Hirst" (Britt 12) in the first act, but Hirst resists such a domination by adopting a language game of resistance in the second act.

Like No Man's Land, the main motif of Farag's play arises from a battle for control between two characters: al-Tabrizi and Quffa. The former is fired with a desire to transform his imagination into a tangible reality, while the latter sticks to the power of reality. Both are obsessed with a hunger for exercising power over each other. In Farag's estimation, al-Tabrizi is a destitute prince who has squandered his fortune on his imagination and adventures. He is a dream vendor who believes in the reality of his dreams. This belief leads him to mix reality with illusion, and truth with lies in the hope of imposing his fabricated imagination as a supreme law on Quffa. On the other hand, Quffa is a realistic character who believes only in the power of reality, not imagination, simply because he is a downright pauper who lives on selling cobblers. In an interview with the Algerian critic Saleh Lambarkia (1948-2015), Farag argues:

Al-Tabrizi is an imaginative person who envisions a dream and believes in its reality. His dilemma consists in combining reality with dreams. This leads him to hold that the caravan that stands for imagination/illusion is nothing more than a reality. ... Unlike al-Tabrizi who was a wealthy prince and has now become a destitute one, Quffa is a realist downright poor shoemaker who insists on living within the limits of reality. His insistence prevents him from joining al-Tabrizi's imagination. (33)

The power struggle between both characters motivates one to figure out that the play represents a power relationship between two conflicting characters: a visionary and a realistic character. One tries to live within the domains of his strong imagination, and the other attempts futilely to escape such domains. In failing to escape such an imagination, Quffa takes the risk of saving al-Tabrizi from being executed. His attempt can be conceived as a direct expression of the victory of imagination over reality.

In No Man's Land, Spooner exercises power over Hirst by hinging on a variety of linguistic tactics that enable him to "wheedle his way into Hirst's confidence" (McGeever). This is best illustrated in the first scene in which Hirst and Spooner celebrate the acquaintance they have. Hirst offers Spooner a glass of whiskey, asking him whether he prefers the whiskey as it is or not. Spooner replies: "as it is ... absolutely as it is." His reply shows that he uses such a question as a pretext for establishing a language game of flattery. He says that this question is a perfect example of the kindness of Hirst. This kindness leads him to feel peace and security never felt before. For all that, he shall not stay long at Hirst's home because he does not like to stay long with others. His feeling 
of peace and security does not spring from his existence at such a comfortable house; but rather, from his belief that Hirst is a reticent man who stands for kindness itself:

Spooner: Thank you. How very kind of you. How very kind. ... Terribly kind of you. ... May I say how very kind it was of you to ask me in? In fact, you are kindness itself, probably always are kindness itself. ... I speak to you ... because you are clearly a reticent man ... and because you are clearly kindness itself. (322f, emphasis mine)

Spooner's speech is replete with the repetition of the word "kind" with its various derivatives, which is mentioned seven times. Such a repetition is a linguistic activity produced by Spooner to give voice to a hunger for power. To achieve such a goal, he embarks on a language game of flattery that aims to trick Hirst into offering him a secure haven where he can feel tranquility. This indicates that the language of a Pinter play "functions primarily as a means of dictating and reinforcing relationships" (Quigley 4) of power. To reinforce such relationships, Spooner, to use Benveniste's words, holds that language is the only medium in terms of which he can constitute himself as "a subject, because language alone establishes the concept of ego in reality, in its reality" (244). In a sense, he uses the language game of flattery as a strategy to gain power by imposing himself as a subject of speech on Hirst's existence. His strategy draws on deploying such a game as well as indexical signs: "you" indicating Hirst and "I" referring to Spooner himself. The index "you" is used seven times, while the pronoun "I" is mentioned only once: "I speak to you." The repetitive use of such indices along with the language game of flattery unfolds the power struggle that exists between the speaker and his addressee.

Spooner insists on using language as a strategy to create power that he does not possess. His attempt, to quote the American novelist Saul Bellow, can be traced back to the notion that "powerlessness appears to force people to have recourse to words" (72). Thus, Spooner plays the language game of giving orders to attain influence over Hirst by forcing the latter to shelter him. His language game aims at forcing Hirst to delve into his memories to tell more truths about his own life. In so doing, Spooner formulates a common ground between himself and Hirst, a relationship that will help him direct and maintain the behavior of Hirst. He introduces himself as "a staunch friend of the arts, particularly the art of poetry" (335). His house is opened to poets who always ask him to evaluate their verse. In return, he asks Hirst to describe his own life, on condition that Hirst be frank about unfolding what he conceals, but Hirst does not obey him. Nevertheless, Spooner pretends to share something with Hirst: 
memory of the bucolic life. This pretension leads Spooner to get the feeling that he is enraptured, asking for more and more information about the sociopolitical-economic background of Hirst:

Spooner: Be frank. Tell me. You've revealed something. You've made an unequivocal reference to your past. Don't go back on it. We share something. A memory of the bucolic life. ... I am enraptured. Tell me more. Tell me more about the quaint little perversions of your life and times. Tell me more ... Tell me more.

Hirst: There is no more. (335f, emphasis mine)

This conversation shows that Hirst is in a subordinating position to Spooner. Such a position results from Spooner's use of the language game of giving orders. His context of utterance is permeated with a central imperative locution: "Tell me," which is repeated five times. Hirst replies to such a locution by stating that "there is no more," mainly because he refuses to be indulged in any power relation with Spooner. His refusal can be traced back to the fact that he has no rapport with Spooner. To empower his language game, Spooner follows two power strategies: first, he tries to convince Hirst that they both share something; second, he utilizes the imperative locutions to induce Hirst to establish a rapport with him. In using the language game of giving orders, Spooner, to use Althusser's words, aims at forcing Hirst to behave as "a subjected being, who submits to a higher authority, and is therefore stripped of all freedom except that of freely accepting his submission" (75). Instead of acting as a powerless character, Hirst resists any force relations imposed on him by Spooner. In short, the language game between the two characters goes like that: when Spooner says, "tell me more," Hirst replies, "there is no more."

Hirst's reaction to the language game produced by Spooner evinces that both characters do not "possess any common memory or outer context to which they could refer" (Napiorkowska 214). To avoid such a failure, Spooner tries another power strategy: the language game of helping Hirst. Such a game motivates Spooner to play the role of a psychoanalyst who probes too deeply into the inner world of Hirst to find out the hidden causes of his psychogenic trauma, a trauma that lies in the lack of a social contact. Spooner does not only analyze such a trauma, but also proposes himself as a possible solution to it. His proposal draws on persuading Hirst that the only solution to this dilemma is to find a close friend that is discovered to be Spooner himself. To reach such an objective, he continues his manipulation of imposing himself on the fabricated existence of Hirst by using an imperative verb: "Heed me." He motivates Hirst to seize the opportunity and accept him as a friend and a relevant witness. To force Hirst to 
seize such an opportunity, he introduces himself as the only friend on whom Hirst can rely to erase his feeling of loss and lack of social contact. He recommends himself by stating that he is the only person of "such rare quality," entreating him to think carefully before accepting or refusing such an offer. For all that, Hirst answers him by saying "No":

Spooner: You need a friend, You have a long hike, my lad, up which, presently, you slog unfriended. ... In other words, never disdain a helping hand, especially one of such rare quality. And it is not only the quality of my offer which is rare, it is the act itself, the offer itself - quiet without precedent. I offer myself to you as a friend. Think before you speak. ... Hirst: No. (339f)

The above-mentioned dialogue encapsulates Spooner's pursuit to impose his will as a powerful character on Hirst. His pursuit arises from a desire to set up a power relation with Hirst. This relationship leads one to hold that "power is not an institution, and not a structure; neither is it a certain strength we are endowed with; it is the name that one attributes to a complex strategical situation in a particular society" (Foucault 1978 93). To improve such a situation, Spooner devises the language game of helping Hirst by employing many imperative locutions, e.g. "Heed me," "never disdain a helping hand," and "Think before you speak." By using the imperative form, Spooner attempts to force Hirst into believing that he is a subjected being who has to submit to Spooner's will and to welcome the conditions of his submission. Instead of acting as a subjected being, Hirst, to cite Althusser's terms, insists on playing the role of a free subject, or rather "a center of initiatives, author responsible for its actions" (75). In this regard, Hirst becomes a free subject who refuses Spooner's desire to exercise any control over him.

In acting as a free subject, Hirst urges Spooner to take one final tactic: the language game of bettering himself. This game leads Spooner to believe that he is a salesperson who should use language as a device to attract the attention of Hirst to the necessity of offering him the job of a secretary, partly because he is a talented person. His very objective is to convince Hirst that he has a lot of talent that fits much the job descriptions of a secretary/a friend in need, urging Hirst to consider him for the post. His talent includes some experience in dealing with tradespeople, "hawkers, canvassers and nuns." Moreover, he can be silent as well as convivial when desired. He can be what Hirst wishes:

Spooner: (To Hirst.) Let me live with you and be your secretary. Hirst: Is there a big fly in here? I hear buzzing. ... 
Spooner: I ask you ... to consider me for the post. I'm extremely good with tradespeople, hawkers, canvassers, nuns. I can be silent when desired or, when desired, convivial. I can discuss any subject of your choice. ... I can be what you wish. (392f)

The language game used in the dialogue, to use Birch's terms, "shows rather than tells" (6). It shows the power relation that exists between Spooner as a slave and Hirst as a master. The master here is not in need of a slave, while the slave longs for a master. That is why, Spooner (the slave) deploys the language game of bettering himself to spur Hirst (the master) into accepting him as a secretary. His language game is actualized by the use of the indices: "I" referring to Spooner and "you" indicating Hirst. The index "I" is mentioned six times, while the pronoun "you" is used twice. The iterative use of the index "I" provides the speaker with a chance to gain what Benveniste calls a sort of "linguistic superiority" (73) that highlights the power struggle preoccupying the addresser (I) and the addressee (you). Such an assessment leads one to infer that power can be "exercised from innumerable points, in the interplay of nonegalitarian and mobile relations" (Foucault 1978 94).

By the end of the play, the struggle for power between Spooner and Hirst reaches the climax: Hirst resists the language games invented by Spooner to subdue him. Whenever Spooner attempts a power strategy to dominate Hirst, the latter stands out against such a strategy, refusing to be controlled by Spooner. His refusal can be traced back to Foucault's belief that "Where there is power, there is resistance. ... This would be to misunderstand the strictly relational character of power relationships. Their existence depends on a multiplicity of points of resistance" (Foucault 1978 96f). These points of resistance are the very indication of the existence of power relations. Without resistance to power, "no power relation can be conceived: where there is power, there is always someone who resists it" (Balan 3).

Hence, Hirst employs a language game of resistance to shun being dominated by Spooner. His game depends on refusing to be involved in any language game invented by Spooner as well as directing the attention of the latter to the necessity of changing the topic of their discussion - Spooner's aim to live with Hirst and be his secretary. Hirst refuses to be an addressee. Instead, he insists on becoming a powerful addresser to keep the peace of his fabricated existence and isolation from any disturbance caused by Spooner's desire for power. This provides Hirst with a chance to gain control over the conversation by adopting the tactic of refusing the reality imposed on him. He pretends that he does not know Spooner. When Spooner asks him to consider his request of being his 
secretary, Hirst answers him by saying "let's change the subject for the last time":

Spooner: Before you reply, I would like to say one thing more. ... Let us content ourselves with the idea of an intimate reading, in a pleasing and conductive environment, let us consider an evening to be remembered, by all who take part in her.

Silence

Hirst: Let us change the subject ... for the last time. (394f)

The power relation between Hirst and Spooner can be analyzed in the light of Lyotard's description of language game, particularly the notion that "every utterance should be thought of as a 'move' in a game" (11). Such a move should be followed by what Lyotard calls "countermoves" (11) that can be expressed in terms of the language game of resistance. In this regard, Hirst deploys such a game as a reaction to Spooner's attempt to impose himself as a supreme law on his existence. Thus, Hirst's language game of resistance is best illustrated in his use of the imperative form: "let's change the subject." Such a form can be modulated as an order in terms of which "the sender is clearly placed in a position of authority" (10), mainly because he expects the addressee, Spooner, to perform the action referred to. That is why the addressee accepts his exile with open arms, stating that he is fated to live in "no man's land. Which never moves, which never changes, which never grows older, but which remains forever, icy and silent" (399).

A close reading of Ali Janah al-Tabrizi and His Servant Quffa shows that the play, like Pinter's No Man's Land, rotates around the idea of power struggle between al-Tabrizi and Quffa. Such a struggle arises from the clash between alTabrizi's imagination and Quffa's realism. To convince Quffa of the reality of his imagination and dreams, al-Tabrizi, unlike Spooner who embarks on different forms of language games, lays emphasis on the language game of giving orders. His tactic/game aims to maintain and direct the behavior of Quffa by forcing him to accept to be "his disciple and alter ego" (El-Halawany 339). To accomplish such a goal, he uses what Wittgenstein calls "the language game of giving orders and obeying them" (127), taking into account that Quffa should play the second part of the game: obeying orders. That is why he dominates the dramatic dialogues with Quffa by insisting on playing the role of a powerful addresser who issues orders to his powerless addressee, waiting for their achievement without delay. This is best demonstrated from the very beginning of the play, particularly in the first scene in which both characters are first introduced. 
In such a scene, Quffa pretends to be blind by covering his eyes with a bandage, wondering if there is a hospitable man in the city to invite a tired homeless shoemaker who is in pain. Impressed by such a call, al-Tabrizi invites him to a banquet, which is later discovered to be an invisible one, "of the kind the servant [Sawab] has been serving to his master for the past couple of days" (Badawi 179). In fact, al-Tabrizi has no food in the house because he has been forced to sell everything, including the stove, the pans, the spoons, the copper dishes, and the glasses. Still, he orders the servant to serve the food quickly for his poor guest. When the servant lays an imaginary tray in front of Quffa, alTabrizi asks him to partake of the imaginary food. Quffa puts his hand eagerly, but touches nothing. When he removes the bandage from his eyes quickly to see the food, he is shocked because he finds no food, concluding that al-Tabrizi mocks him. That is why he is afraid of al-Tabrizi, making up his mind to go along with him in the hope of the arrival of a real food. He implores al-Tabrizi to forgive him because he has not seen such a great meal for a long time, acting as if he were enjoying real fabulous food:

Ali (taking him by arm): Come and sit here at the middle of the table and help yourself to any dish you fancy; don't be shy! I know how hungry you are. Look at this nice white bread. ... Do eat, my guest. You're weak; you need nourishment. Try this chickens stuffed with pistachios.

Quffa (As though tasting it and beginning to enjoy the game): Yum-yum! By God, master, this food's the best I've ever eaten. (311)

Through al-Tabrizi's speech with Quffa, one can figure out that al-Tabrizi is a powerful character: he embarks on the language game of giving orders to subject Quffa to submission. His language game enables him to enforce his imagination as a supreme law on Quffa; therefore, his context of utterance is replete with the imperative locutions, e.g. "come and sit here," "help yourself," " don't be shy," " look at this," " do eat," and "try this." Such imperative locutions, to use Lyotard's terms, are "prescriptions" invented by the speaker (al-Tabrizi) to maintain and direct the behavior of the addressee (Quffa). In this regard, al-Tabrizi is placed in "a position of authority" that uses language as a tactic to control the addressee because he "expects the addressee to perform the action referred to" (10). Thus, Quffa becomes a subjected being who ought to submit to a higher authority. His submission can be traced back to the fact that al-Tabrizi's language game does not only deprive him of feeling any sense of freedom, but leads him to welcome his submission and domination by enjoying the imaginary dishes of al-Tabrizi.

In acting as a subjected being, Quffa begins to step into "the scene of makebelieve" (El-Halawany 348) by enjoying the enactment of eating the invisible 
meal. This is best illustrated when he behaves as if "he were frantically gobbling different foods from all the dishes near and far, picking up what he drops and wiping off what dribbles from his mouth" (311f). Moreover, when Quffa gets hiccups because of eating too much from al-Tabrizi's imaginary dishes, he asks for water to get rid of such hiccups. Al-Tabrizi replies that the house contains no water as he drinks only the best wine, ordering the servant to bring the wine to his guest quickly. Thus, the servant enters, carrying the imaginary wine and glasses. As soon as al-Tabrizi serves such an imaginary wine to Quffa, the latter pretends to get drunk as a sponge, asking for more imaginary glasses because he has never drunk like them before. When informed that al-Tabrizi has stolen the wine from the very cellar of Omar Khayyam, Quffa slaps al-Tabrizi on the face. Such a slap forces al-Tabrizi to get angry with Quffa, deciding to punish him with an imaginary whip. Quffa kneels down pleading for forgiveness and mercy, but al-Tabrizi shows no mercy. Quffa demonstrates his best to escape such whipping, but he feels that he has been lashed, crying out in pain, swearing that he hears the whip with his own ears, swishing in the air:

Ali: You'll pay with your life for this. Come here!

Quffa (Drops on the ground with fear and shakes violently): I'm lost. Master, I'm only your slave to whom you've been so kind. ...

Ali (Stands over Quffa and makes as though he was whipping him.) Here, for your impudence. Take this.

Quffa (Jumps away as if stung; feels his back in terror. Aside:) I swear I could hear the whip with my own ears, swishing in the air. I've been whipped. (He cries and feels his body in pain.) Oh! My back, my back! Ali: Come here! (313)

The scene of whipping outlines the power relationship between Quffa and alTabrizi. It also brings into prominence Wittgenstein's belief that "in the practice of the use of language, one party calls out the words, the other acts on them" (6). If such statement is carried a step further, one can sum up that the power struggle between both characters goes like that: one party calls out words/games, the other should act upon them. When such an other (Quffa) shows some forms of resistance, the addresser (al-Tabrizi) punishes him. In this regard, Quffa's slapping of al-Tabrizi is conceived to be a form of power resistance created by Quffa to resist al-Tabrizi's attempt to keep him in subjection. To suppress such a resistance, al-Tabrizi adopts what Lyotard names "a countermove" which is best manifested when he orders the servant to hand him a whip to chastise Quffa. This assessment results from the notion that al-Tabrizi creates a linguistic tactic abounding with imperative speech acts: "come here," "fetch me," and "take this." 
The repetitive use of such locutions highlights al-Tabrizi's desire for power, as well as proving that language is a means of power, or as Lyotard puts it: "to speak is to fight" (8). Motivated by Lyotard's belief, al-Tabrizi devises a power strategy that enslaves Quffa by coercing him into feeling the pains of the imaginary whip. This motivates one to infer that Farag's al-Tabrizi and Quffa, and Pinter's Spooner and Hirst are engaged in a power struggle and the winner is the one who deploys a power strategy that enables him to direct the behavior of the other.

Hence, Quffa's statement that he "can feel the pain where the whip hit" (313) him epitomizes a total submission to al-Tabrizi's power strategy. His submission, to borrow Foucault's terms, comprises "a mechanism of power" by which Quffa acts in a certain way to "increase the subjected forces and to improve the force and efficacy of that which subjects" him (Power/Knowledge 104). To improve such forces, Kafur, a renaming of Quffa, accepts to follow al-Tabrizi on a journey to a legendary place named by the latter "the mountain Qaf" (313). When both characters reach the mountain Qaf, a city near the Chinese borders, they are taken aback by its poverty and large number of beggars. Frustrated by such a scene, Quffa/Kafur blames al-Tabrizi for bringing him to a place where he will never be able to find a craft to work at. Al-Tabrizi announces that the best suitable profession for them both is to trick the people of such a miserable town into holding that they are both rich tourists. He asks Quffa to spread the rumors that he is the richest man in Baghdad as well as on the earth. Such a rumor can become a recognized reality on condition that Quffa play the role of a clever salesman who uses the power of language to sell al-Tabrizi's illusion as if it were a precious stone. To accomplish such an aim, he urges Quffa to try attributes of power rather than those of weakness and poverty:

Ali: You must sell me as you would a precious stone, and you must do it like a gold salesman.

Quffa: What shall I say?

Ali: Say anything that comes to your mind as long as you play your part well. Act naturally.

Quffa: Naturally?

Ali: Yes. Give free rein to your imagination. ... Try to describe me. Who am I? ... Superb. But always make sure you say the right thing at the right time. And don't overdo it. (318)

This dialogue reflects al-Tabrizi's power relationship with Quffa, a relationship that leads him to play the role of a power instructor. This instructor teaches Quffa some practical lessons on how power is exercised to direct and maintain the 
behavior of the other in terms of linguistic tactics. To assert his presence as a powerful instructor, he produces many imperative locutions that arise from his insistence on deploying the language game of giving orders. Such a game is used nine times in his utterance: "you must sell me," "you must do it," "Say anything that comes to your mind," "Act naturally," "Give free rein to your imagination," "Try to describe me," "Superb," "make sure you say the right thing," and "don't overdo it." Indeed, such locutions are a form of an exercise of power practiced by the addresser (al-Tabrizi) to act upon the addressee (Quffa) by transforming him into a powerful dominator instead of being a powerless dominated. Motivated by al-Tabrizi's lessons, Quffa provides a new description of al-Tabrizi as "the chief merchant of all chief merchants under the sun," not as a destitute prince. This indicates that Quffa becomes dominated and "transfigured by the power of al-Tabrizi's poetic imagination, the ingenuity of his word play and artistry" (El-Halawany 354) of his power strategy.

Motivated by al-Tabrizi's poetic imagination, Quffa spreads the rumors about the fabulous wealth, saying that his master's caravan consists of "three hundred mules, each led by a special slave and bearing a chest packed with gold and precious stones" (323). Thus, when the news of al-Tabrizi's richness reaches the king, he asks al-Tabrizi's to marry his daughter, the royal princess. This urges Quffa to rebel against his master for the first time in the play, declaring that the princess should be his wife, not al-Tabrizi's because he has seen her before him. His reaction stems from the belief that he and al-Tabrizi are operating with his own capital; thus, he tries to remind al-Tabrizi of the money he has borrowed from him. He criticizes al-Tabrizi for insisting on calling himself a "master" and addressing him as a "slave." Al-Tabrizi replies that such discrimination is not his own; rather, it is the outcome of the law of nature which classifies humans into slaves and masters. With this in mind, al-Tabrizi contends that such a law gives him the right to marry the princess, while Quffa ought to marry her maid as he is the valet. To avoid being involved in a dispute with al-Tabrizi over marrying the princess, Quffa suggests that he will accept al-Tabrizi's marriage to the princess on condition that he share the princess with al-Tabrizi, or he will reveal their secret to the king:

Quffa (Pulling Ali to a corner, aside): I saw her too, maybe even before you did. I want to marry her.

Ali (Aside): But the King wants to marry her to me.

Quffa: (Aside): No, no, no. We're operating with my own capital.

(Wagging his notebook at him.) She'll be my wife.

Ali (Aside): By all means. Tell the vizier that. ... 
Quffa (Aside): Do you want me to be killed? Listen, you marry her and then let's share her between us. (330)

This rapid dialogue summarizes Quffa's attempt to resist al-Tabrizi's pursuit to enforce his imagination as a supreme law on him. To resist such a pursuit, he, like Hirst, adopts the language game of resistance, a game which ascertains Foucault's notion that where there is power, there is resistance. This resistance endows Quffa with a chance to act the role of a free speaking subject who uses the power of language to assert his existence as a powerful addresser, not a powerless addressee. Thus, he opposes al-Tabrizi's project to marry the princess by repeating the adverb "no" three times. His "noes", like Hirst's, reveal a powerful will to maintain his space position as a free subject. To accomplish such a goal, he uses many indexical signs: "you" indicating al-Tabrizi, "I" referring to Quffa, and "her" standing for the princess. The index "you" is employed three times; the pronoun "I" is used six times; and the indexical sign "her" is mentioned twice. The repetitive use of such indices constructs what Elam calls "the dramatic dialect in which 'I' becomes 'you'" (142). This dramatic dialect illustrates the power struggle between both characters, a struggle that leads the I/speaker, Quffa to force the you/addressee, al-Tabrizi into sharing the her/princess between them both. Unlike Spooner, who surrenders to Hirst's will and stays in no man's land, Quffa's language game helps Farag depict a new Quffa that wields the mechanism of resistance to force his dominator(al-Tabrizi) into submission.

Inspired by his position as a free speaking subject, Quffa runs out of patience with his master. He asks al-Tabrizi to settle their accounts, but al-Tabrizi insists that they should wait for the arrival of the caravan. To take revenge on al-Tabrizi, Quffa reveals their secret to the king in return for thirty dirhams; therefore, alTabrizi is sentenced to death. Such a sentence makes Quffa sympathize with him by disguising as a custodian of al-Tabrizi's caravan, asking the citizens of the city about a royal personage called Ali Janah al-Tabrizi. Pretending to be shocked at the sight of al-Tabrizi's humiliation, he scolds the chief merchant and the executioner for degrading his master. When the executioner unties al-Tabrizi, Quffa tells him that they should escape immediately to save the caravan from the bandits. By listening to such advice, al-Tabrizi escapes execution, accompanied by Quffa and the princess to meet the caravan:

Quffa (In his natural voice, aside to Ali:) Master, we must escape at once. I'm Quffa.

Ali: (Aside to Quffa): What's delayed the caravan? 
Quffa: What can I say to him? (Aside to Ali:) Listen, my friend, if we hang around for one minute longer, bandits will get to the caravan before we do. Hurry! (348)

Quffa's context of utterance draws on the index "we" that refers to al-Tabrizi and Quffa himself. The iterative use of such an index helps Farag formulate a dramatic dialect in which the addresser/I and the addressee/you become a "we." This "we" stands for a new power relationship, a relationship that enables alTabrizi to impose his imagination/caravan as a supreme law on Quffa.

The play, therefore, ends with the sweeping victory of al-Tabrizi's dream over Quffa's realism. This victory is the outcome of a power struggle between two different dramatic characters: "the dreamer Tabrizi and the down-to-earth Quffa, the Don Quixote and Sancho Panza" (Badawi 182). The interaction between the two characters unfolds the power relations between the powerful and powerless as well as the social dreams that dominated the Egyptian society during the 1960s, particularly when Gamal Abdel Nasser rose to Power. This assessment arises from Qaid Diab's belief that the play contains a sense of social and political satire that explains Farag's attitude towards Nasser as well as the relationship between the Egyptians and Nasser's dreams. In this regard, al-Tabrizi symbolizes Nasser, while Quffa stands for the Egyptians who have a complete confidence in Nasser's political and social agenda, or rather al-Tabrizi's caravan. This leads one to infer that the power relationship between al-Tabrizi and Quffa epitomizes Nasser's politics that aims to subject the Egyptians into submission. Like alTabrizi, Nasser is a dream vendor who believes in the reality of his dreams/caravan. On the other hand, Quffa, deluded by al-Tabrizi's imagination, represents the Egyptians waiting for the arrival of the caravan up till now, but in vain:

Many critics argue that Ali Janah al-Tabrizi and His Servant Quffa has an overt political message that reflects the relationship between Gamal Abd al-Nasser and the Egyptian people. Al-Tabrizi stands for Nasser, while Quffa symbolizes the Egyptians. The relationship between both characters highlights Nasser's politics that rest on selling dreams to the Egyptians who, like Quffa, never had the benefit of such politics [caravan]. (93)

In approaching Pinter' and Farag's theatre in light of Foucault's conception of power and Wittgenstein's theory of language games, one can conclude that power is not a concrete concept. Rather, it is a relationship between two individuals. This relationship reflects how a Pinter and a Farag character manipulate language as an instrument to dominate and control the behavior of 
the other. Bearing this in mind, I would like to make four main points regarding the dramatic achievement of both playwrights. First, both Pinter and Farag mould a dramatic vision that illustrates the motif of power struggle. This motif portrays how one character wields a linguistic tactic of power to dictate and reinforce his/her singular space position as a supreme law on the other.

Second, to dramatize such a motif, both dramatists develop a new stage language. This language enables them both to create a dramatic vision, a vision that shows how power is exercised between characters as well as the aesthetic function performed by the dramatic dialogue in negotiating power relationships. However, both hold a different approach to theatrical language. Pinter contends that dramatic language is a highly ambiguous business simply because below the word spoken is the thing unknown and unspoken. To remove such an ambiguity, the artist should supply his/her characters with a legitimate elbowroom through which they can reveal the unspoken in the text. Unlike Pinter, Farag asserts that dialogue is the essence of theatre. It is the best medium in terms of which the writer can elucidate the struggle between characters. To clarify such a struggle, the language of a dramatic dialogue should be a clear expressive well-focused one that expresses in a direct way the dramatic crisis between characters.

Third, Pinter and Farag's motif of power are best translated in No Man's Land and Ali Janah al-Tabrizi and His Servant Quffa. Thus, when making a comparison between these two pieces, significant thematic and technical analogies regarding the issue of power struggle can be discovered. Pinter's play depicts a power relationship between Spooner and Hirst, two conflicting characters who are engaged in a battle for control. The former deploys a variety of language games to exercise power over the latter who resists such games by adopting the language game of resistance. Like Pinter's, Farag's piece provides a plot that theatricalizes the idea of power struggle, particularly how the characters employ language as a strategy to subdue each other. To highlight such a struggle, Farag presents a linguistic battle between two contradictory characters: al-Tabrizi and Quffa. This struggle results from al-Tabrizi's insistence on imposing his imagination as a supreme law on Quffa who, unlike Hirst, shows no resistance by believing in the reality of such an imagination.

Finally, in addressing the power struggle between Spooner and Hirst, and between al-Tabrizi and Quffa, Pinter and Farag draw on different forms of Wittgenstein's theory of language games. Pinter's Spooner deploys fourlanguage games - the language game of flattery, giving orders, bettering himself and helping Hirst. Such games endeavor to compel Hirst to act as a subjected being that should submit to a higher authority, mainly because he has been stripped of all freedom except that of freely accepting his submission. Still, Hirst defends his freedom and fabricated existence by resorting to the language game 
of resistance. In so doing, he acts as a free subject who resists Spooner's language game by repeating the adverb "no" more than once. Unlike Spooner, Farag's alTabrizi embarks only on the language game of giving orders. His very objective is to spur Quffa into acting as a subjected being, taking into account that Quffa should perform the second part of the game: obeying orders. Like Hirst, Quffa insists on behaving as a free subject, an individual responsible for his action by adopting the language game of resistance, which is best reflected in duplicating the adverb "no" three times. In short, the language games devised by Pinter's and Farag's characters bring into prominence the fact that every utterance should be thought of as a move in a game.

\section{Endnotes}

${ }^{1}$ See Appendix for the Arabic phonetic symbols used according to IPA.

${ }^{2}$ All translations from Arabic are mine.

\section{Works Cited}

\section{A- English}

Althusser, Louis. Lenin and Philosophy, and Other Essays. Trans. By: Ben Brewster. New York: New Left, 1978. Print.

Amin, Dina. Alfred Farag and Egyptian Theater: The Poetics of Disguise, With Four Short Plays and a Monologue. Syracuse: Syracuse U P, 2013. Print.

Ara, Roshan. "Wittgenstein's Concept of Language Game." Al-Hikmat 26 (2006): 47-62. Print.

Badawi, Muhammad. Modern Arabic Drama in Egypt. New York: Cambridge U P, 1987. Print.

Balan, Sergiu. "M. Foucault's View on Power Relations." Cogito 2:2 (2014): 16. Print.

Bellow, Saul. Saul Bellow: Letters. London: Penguin, 2012. Print.

Benveniste, Emile. Problems in General Linguistics. Trans. By Mary Meek and Coral Gables. New York: U of Miami P, 1973. Print.

Billington, Michael."No Man's Land: A Review." The Guardian 24 April 1975. Web.

Birch, David. Language, Literature, and Critical Practice: Ways of Analysing Text. Routledge: London, 1989. Print. 
Britt, Brian. "'Are You Speaking?' : A Speech Act Analysis of Pinter's A Kind of Alaska and No Man's Land." Honors Thesis (2002): 1-46. Web. 5 Jan 2017. <http://www.etd.ohiolink.edu.>

Elam, Keir. The Semiotics of Theatre and Drama. London: Routledge, 2002. Print.

El-Halawany, Mona. "The Artist / Faith Healer / Diviner as a Metaphor of Sustenance in Brian Friel's Faith Healer and Alfred Farag's Ali Janah alTabrizi and His Servant Quffa." Language in Literature: English and Arabic Perspectives 4 (1997): 335-364. Print.

Esslin, Martin. Pinter: A Study of His Plays. London: Eyre Methuen, 1977. Print. Farag, Alfred. Ali Janah al-Tabrizi and His Servant Quffa. (Trans.) Rasheed elEnany and Charles Doria. In (Eds.) Salma Khadra Jayyusi and Roger M. Allen (1995), 305-351.

Foucault, Michel. Aesthetics, Method, and Epistemology. (Trans.) Robert Hurley and Others. New York: the New Press, 1997. Print.

----. Foucault Live (Interviews, 1961-1984). Trans. Lysa Hochroth and John Johnston. New York: Semiotext, 1996. Print.

----.."Truth and Power." The Foucault Reader. Ed. Paul Rabinow. New York: Pantheon Books, 1984, 51-75. Print.

----. Power/Knowledge, Selected Interview and Other Writing, 1977-1984. Ed. Colin Gordan. London: Harvester Press, 1980. Print.

-----. Discipline and Punish: The Birth of the Prison. Trans. Alan Sheridan. New York: Vintage Books, 1979. Print.

----. The History of Sexuality. Vol 1: An Introduction. Trans. Robert Hurley. New York: Pantheon Books, 1978. Print.

Jayyusi, Salma Khadra, and Roger M. Allen, eds. Modern Arabic Drama: An Anthology. Bloomington: Indiana U P, 1995. Print.

Latrell, Craig. "As It Is." Yale Theatre (1977): 160-63. Web. 5 Jan. 2017.

Leeuwen, Richard van. "Lies, Illusions and Authority: The Thousand and One Nights and Arabic Comic Theatre." The Performance of the Comic in Arabic Theatre: Cultural Heritage, Western Models and Postcolonial Hybridity(2005): 210-24. Print.

Lyotard, Jean-Francois. The Postmodern Condition: A Report on Knowledge. (Trans.) Geoff Bennington and Brain Massumi. New York: Minnesota U P, 1995. Print.

McGeever, Kathleen M. "Exiles in No Man's Land and The Caretaker: A Comparison of Two of Pinter's Tramps." Paru dans Cycnos 14:1 (2008): n. pag. Web. 5 Jan 2017.

Napiorkowska, Krystyna. "Harold Pinter's No Man's Land: Communication in the Making." Studia Anglica Posnaniensia 14:9 (2008): 210-15. Print. 
Pinter, Harold. "Harold Pinter: Art, Truth \& Politics." The Nobel Foundation. 7 Dec 2005. Web. 5 Jan. 2017.

-----. Plays Three: The Homecoming, Tea Party, The Basement, Landscape, Silence, Night, That's Your Trouble, That's All, Applicant, Interview, Dialogue for Three, Tea Party, Old Times, No Man's Land. London: Faber, 1997. Print.

-----. "Introduction: Writing for the Theatre." In Pinter (1996), vii-xiv.

----. Plays One: The Birthday Party, The Room, The Dumb Waiter, A Slight Ache, The Hothouse, A Night Out, The Black and White, The Examination. London: Faber and Faber, 1996.

Quigley, Austin. The Pinter Problem. Princeton: Princeton U P, 1975. Print.

Raby, Peter, ed. The Cambridge Companion to Harold Pinter. Cambridge: Cambridge U P, 2009. Print.

Rosca, Alina-Elina. Multilevel Representation of Power in Harold Pinter's Plays. New York: Peter Lang, 2015. Print.

Wittgenstein, Ludwig. Philosophical Investigations. (Tran.) G. E. M. Anscombe. Oxford: Blackwell, 1958. Print.

\section{B- Arabic}

فرج، ألفريد. دليل المتفرج الذكي إلي المسرح: الملاحة في بحار صسعة. القاهرة: الهيئة العامة للكتاب، .1919

-----.- حلاق بغداد، بقبق الكســلان، علي جناح التبريزي وتابعه قفة. القاهرة: الهيئة العامة للكتاب، .1911

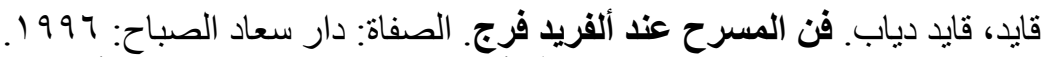

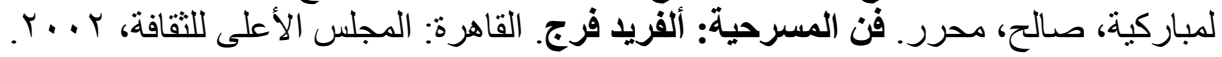




\begin{tabular}{|c|c|c|}
\hline \multicolumn{3}{|c|}{$\begin{array}{c}\text { APPENDIX } \\
\text { List of Arabic Phonetic Symbols (from IPA) }\end{array}$} \\
\hline Arabic Consonant & Description & Symbol \\
\hline$i$ & Voiced glottal stop & $/ \mathrm{L} /$ \\
\hline ب & voiced bilabial stop & $/ \mathrm{b} /$ \\
\hline$ت$ & Voiceless dento-alveolar stop & $/ \mathrm{t} /$ \\
\hline$\dot{H}$ & Voiceless interdental fricative & $/ \theta /$ \\
\hline ج & voiced post-alveolar fricative & $/ \mathrm{g} /$ \\
\hline$\tau$ & voiceless pharyngeal fricative & $/ / \mathrm{h} /$ \\
\hline$\dot{\tau}$ & voiceless uvular fricative & $/ \mathrm{x} /$ \\
\hline د & Voiced dento-alveolar stop & $/ \mathrm{d} /$ \\
\hline$\dot{j}$ & Voiced interdental fricative & $/$ / / \\
\hline 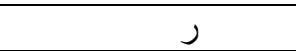 & Voiced alveo-palatal trill & $/ \mathrm{r} /$ \\
\hline$j$ & Voiced alveolar fricative & $|z|$ \\
\hline س & Voiceless alveolar fricative & /s/ \\
\hline ش & Voiceless alveo-palatal fricative & $1 / 1$ \\
\hline ص & Voiceless velarised alveolar fricative & $/ \mathrm{S} /$ \\
\hline 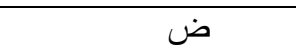 & Voiced velarised dento-alveolar stop & $/ \mathrm{D} /$ \\
\hline b & Voiceless velarised dento-alveolar stop & $/ \mathrm{T} /$ \\
\hline ظ & Voiced velarised interdental fricative & /Z/ \\
\hline$\varepsilon$ & Voiced pharyngeal fricative & $/ \mathrm{\varsigma} /$ \\
\hline$\ddot{\varepsilon}$ & Voiced uvular fricative & $/ \mathrm{\gamma} /$ \\
\hline ف & Voiceless labio-dental fricative & $/ \mathrm{f} /$ \\
\hline ق & Voiceless uvular stop & /q/ \\
\hline 5 & Voiceless velar stop & $/ \mathrm{k} /$ \\
\hline J & Voiced alveolar lateral & $/ \mathrm{l} /$ \\
\hline 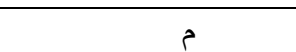 & Voiced bilabial nasal & $/ \mathrm{m} /$ \\
\hline ن & Voiced alveolar nasal & $/ \mathrm{n} /$ \\
\hline هـ & Voiceless glottal fricative & $/ \mathrm{h} /$ \\
\hline 9 & Voiced labiovelar glide & $/ \mathrm{w} /$ \\
\hline s & Voiced palatal glide & $/ \mathrm{j} /$ \\
\hline
\end{tabular}

\begin{tabular}{|c|l|c|}
\hline Arabic Vowels & Description & Symbol \\
\hline Diacritic & Short low front vowel & $/ \mathrm{a} /$ \\
\hline Diacritic & Short high front vowel & $/ \mathrm{i} /$ \\
\hline Diacritic & Short high back vowel & $/ \mathrm{u} /$ \\
\hline or $s$ & Long low front vowel & $/ \mathrm{a}: /$ \\
\hline $\mathrm{s}$ & Long high front vowel & $/ \mathrm{i}: /$ \\
\hline s. & Long high back vowel & $/ \mathrm{u} / /$ \\
\hline
\end{tabular}

